\title{
ORIGINAL ARTICLE \\ Use of forest strata by bats according to wing morphology and habitat complexity in a fragment of tropical dry forest (Colombia)
}

\author{
María H. Olaya-Rodríguez ${ }^{1,2, *}$, Jairo Pérez-Torres ${ }^{1}$, María C. Londoño-Murcia²
}

${ }^{1}$ Laboratorio de Ecología Funcional, Unidad de Ecología y Sistemática (UNESIS), Departamento de Biología Pontificia Universidad Javeriana, Carrera 7 No. 40-62, Bogotá, D. C., Colombia

${ }^{2}$ Biodiversity assessment and monitoring program, The Alexander von Humboldt Institute for Research on Biological Resources, Calle 28A No. 15-09, Bogotá, D. C., Colombia

*Corresponding author:

m_rodriguez@javeriana.edu.co

DOI: https://doi.org/10.14709/ BarbJ.12.1.2019.11

Keywords: assemblage, chiroptera, morphology, spatial heterogeneity theory

received: March, 11th 2019 accepted: December, 3rd 2019

\begin{abstract}
The high spatial heterogeneity of tropical forests is one of the main causes for its vast biodiversity, along with other factors such as resource partitioning and habitat structure. Bats are a major component of these ecosystems and provide different functional roles and ecosystem services. This aspect is especially important in highly fragmented environments such as dry tropical forests, where the mechanisms that control the structuring of bat assemblages in these environments are still unknown. The present study examined the use of forest strata by a bat assemblage, which was evaluated throughout 16 nights of sampling during the rainy season (September 2009) in a tropical dry forest in Colombia. Using elevated and ground mist nets, a total of 170 bats from 13 different species were captured. Of these, 110 individuals and four unique species were captured at the Available Height for Foraging (AHF) (5.4-8.4 $\mathrm{m}$ ) and 60 individuals and five unique species at the understory height (0-3 $\mathrm{m})$. Variation in the vertical distribution of bat species revealed differences in feeding habits and foraging strategies, demonstrating species-specific patterns on how bats move through the forest according to leaf density and wing morphology. A possible relationship was detected between the wing aspect ratio and the forest layer in which the bats forage, probably according to food resource distribution, which has the potential to influence the structure of bat assemblages, and of the functional dynamics of these animals in tropical dry forests.
\end{abstract}

\section{INTRODUCTION}

The use of forest strata, defined as the different layers of plants species in the vertical dimension of forests, concerning bat flight behavior, has been studied since the mid-twentieth century (Staton \& Poulton 2012). However, there continues to be little research on Neotropical areas, especially in Colombia, one of the highest-ranking countries in bat species diversity (205 species) (Solari et al. 2013, Ramírez-Chavez et al. 2016), mainly because of the difficult access to the forest canopy (Kalko \& Handley 2001).

Vertical stratification on bats has been described according to variation in capture success between the high and low layers of forest vegetation (Bernard 2001, Kalko \& Handley 2001). Explanations of observed differences in vertical distribution have focused on the availability of food and roost resources (Ascorra et al. 1996, Bernard 1997, 2001, Simmons \& Voss 1998, Kalko \& Handley 2001), and on how vegetation structure is related with body size and morphology features. Habitat stratification is strongly marked in tropical forests, where differences in factors such as solar radiation and water availability result in high habitat complexity (August 1983) that also affects animal assemblages (Pereira et al. 2010, Villalobos \& Arita 2014, López-González et al. 2015).

Ecological morphology analyzes the relationships between morphological aspects of an organism and their ecology and behavior, particularly concerning interactions with their environment (Selaya 2001, Aguirre et al. 2002, Hodgkison et al. 2004). Wing morphology is considered a valuable tool when analyzing the structure of bat assemblages (Selaya 2007). The hypothesis arising from the aerodynamic theory of flight states that wing morphology determines the habitat in which the bat is able to forage (Norberg \& Rayner 1987, Selaya 2007). For example, long pointed wings enable fast and straight flight in open spaces, while short wide wings are better adapted for slower and more maneuverable flight in areas with a high prevalence of obstacles (Kalko 1997). There is a broad spectrum of wing shapes and sizes among bat species, described by morphological indexes such as wing loading $(\mathrm{WL})$, aspect ratio $(\mathrm{A})$ and tip index (I). These indexes refer to flight velocity, weight carried during flight and holding and maneuverability within dense vegetation (Findley \& Wilson 1982, Selaya 2001). For example, in the Phyllostomidae family, either wings are adapted to fly in open spaces, or specialized to manoeuver and fly close to vegetation (Norberg \& Rayner 1987). 
In this study we attempted to evaluate the hypothesis that there is a difference in the use of forest strata within a fragment of tropical dry forest in the Caribbean region of Colombia by some bat species, which corresponds to their wing morphology traits. To examine the influence of wing morphology on the vertical distribution of bat species, two vertical layers were defined: (I) understory, characterized by high cover of shrubby and herbaceous species that might hinder flight and increase the energy expenditure of bats when moving through this zone, and (II) the Available Height for Foraging (AHF), defined as the range of space between the upper edge of the understory and the lower edge of tree canopies, dominated by open spaces that permit aerial movement, in which bats search for food and resting places (Pérez-Torres 2004). We expected that bat species with long, narrow and pointed wings flew across open spaces, like AHF, while bat species with short and wide wings were better adapted to fly slowly and in a maneuverable way through many obstacles, as in the case of understory (Kalko 1997).

\section{MATERIALS AND METHODS}

\section{Study area}

The Guacharacal forest has an approximate area of 15 ha $\left(75^{\circ} 32^{\prime} 78^{\prime \prime}\right.$ W, $8^{\circ} 11^{\prime} 72^{\prime \prime}$ N) (Fig. 1) and is part of the Civil Society Nature Reserve Hacienda Betancí-Guacamayas in the department of Córdoba, Colombia. This reserve preserves fragments of tropical dry forest that have more than 50 years with little evidence of intervention. Dominant trees in this forest belong to the families Arecaceae, Araliaceae, Lauraceae, Melastomataceae, Rubiaceae, and Verbenaceae families (Ríos-Blanco \& Pérez-Torres 2015).

The tropical dry forest has been reduced to $2 \%$ of its original coverage throughout the country (Gast et al. 1997, Díaz 2006). Due to a long history of environmental degradation in Córdoba, most ecosystems have been transformed into anthropogenic savannas as a result of unplanned agriculture and livestock production (Pizano et al. 2014, Pineda-Guerrero et al. 2015).

In the department of Córdoba, average annual temperature varies between 27 and 28 ㅇ. The relative humidity is above $80 \%$ almost all year long and exhibits minor temporal variations between the dry season (82\%) and the rainy season (85\%) (Ballesteros et al. 2006). The tropical dry forest of this department has an average precipitation of $1210 \mathrm{~mm} /$ year and two seasons: the dry season, from October to March, and the rainy season, from April to September (Rangel-Ch et al. 2011). According to Ballesteros (2015), in the tropical dry forest, plant growth, flowering and fruiting processes are highly seasonal and many plants synchronize these attributes with the transition period from dry to rainy season, while trees are deciduous (Prado 2000), as an adaptive strategy facing water stress in the dry season (Hayden et al. 2010).

To characterize vegetation of the two strata of interest, five plots of $10 \times 10$ meters were established around the stations where the mist-nets were placed (Fig. 1). Richness of plants, number of individuals, vegetation density, and percentage of vegetation cover were measured at each stratum of

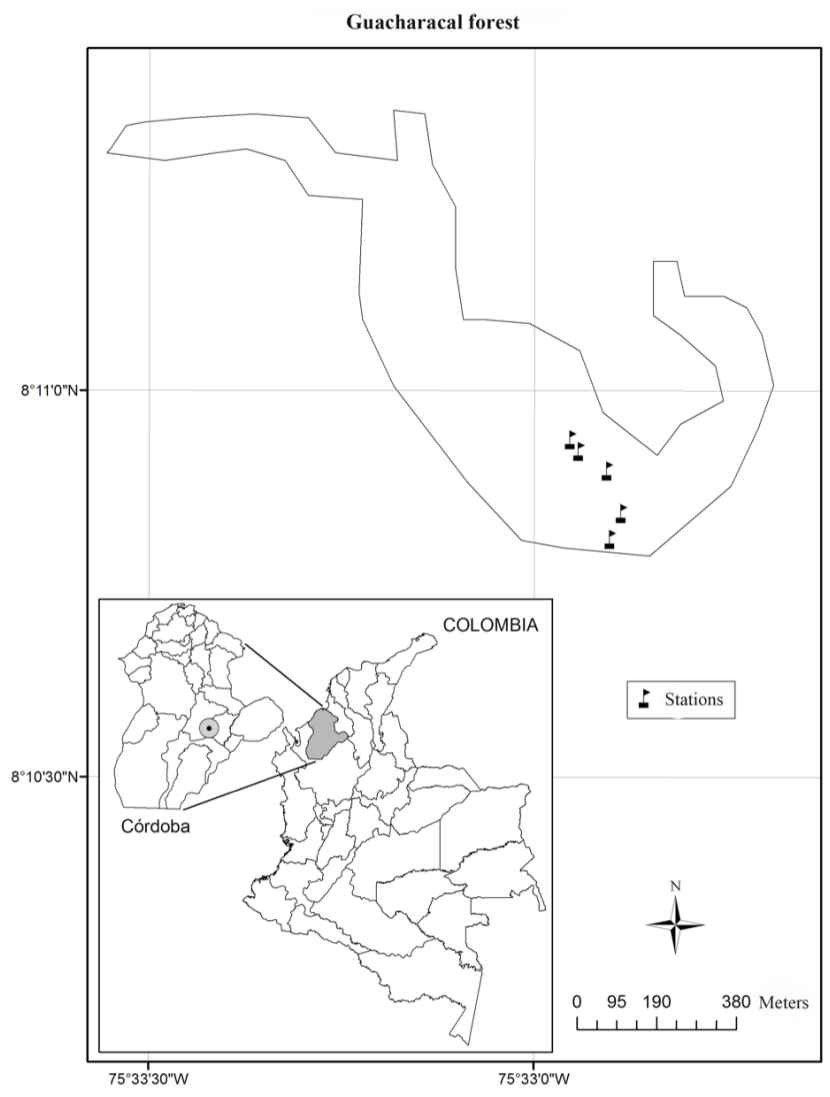

Fig. 1 - Location of five stations with ground and elevated mist-nets in the Guacharacal forest (department of Córdoba, Colombia).

each plot. In order to determine plant richness, systematic samples were collected and identified in the Herbarium of the Pontificia Universidad Javeriana. The number of individuals or abundance of these species corresponds to the count of specimens in the field. Vegetation density was estimated following the intercept point sampling method (Bobrowiec \& Tavares 2017) with an $8 \mathrm{~m}$ long pole, counting the number of contacts with branches at each corner of the plot. Percentage of vegetation cover was measured through a spherical densiometer (Lemmon 1956, 1957), as described in Seidel et al. (2011). Comparisons for vegetation variables between layers were performed using paired t-tests. Average vegetation cover values, that were not normally distributed, were analyzed using a Wilcoxon test (Wilcoxon 1945).

Vegetation sampling resulted in the identification of 23 families, from which 19 samples were identified to the level of genera, and only 9 samples were identified to the level of species. The abundance of plants belonging to the genera Ficus, Cecropia and Vismia in the AHF zone, and of Piper and Sabal mauritiformis in the understory was very high, all of which are consumed by Neotropical bats. Plant species richness did not differ significantly between the two layers (AHF= 9 species, understory $=7$ species),$p>0.05$ ). However, the abundance was greater in the understory than in the AHF zone $(t 4=-3.51, p<0.05)$, as well as the percentage of cover $(T=0.0001, p<0.05)$, and the number of contacts with branches $(t 4=-8.69, p<0.001)$.

\section{Bat capture}

Five sampling stations (Fig. 1) were selected according to the availability of trees between 12 and 15 meters of height 
to set mist nets. This represents the average canopy height of the tropical dry forest in the Caribbean region (CastellanosCastro \& Newton 2015). At each of these stations two mist nets were installed, one elevated (AHF; between 5.4 and 8.4 meters of high) aligned over the other one, at a ground level (understory; between 0 and 3 meters of height). In total five elevated nets of $6 \times 3$ meters were placed at the AHF, while three nets of $6 \times 3$ meters and two nets of $12 \times 3$ meters were used in the understory. Two trees in each station were climbed using the single rope technique (Anderson et al. 2015) to install the elevated nets at AHF. The ground nets were located just beneath the elevated ones in the understory zone. Given the difficulty to access the canopy, we decided to keep the mist nets static during the fieldwork, although it is well-known that bats can learn the location of the mist nets and avoid them (Marques et al. 2013).

We opened all mist nets during 16 nights (in a cycle of two nights of sampling and one night of rest) in September 2009 , from 18:00 to 06:00, with a monitoring frequency of one hour, resulting in a total sampling effort of 2136 hours/ net (understory: 1246 hours/net and AHF: 890 hours/net). We removed captured individuals from the net and placed them in cloth bags for species identification. A reference collection of voucher specimens was created including a male and a female of each species, and these were deposited in the mammal collection of the Museo Javeriano de Historia Natural of Pontificia Universidad Javeriana (accession numbers MPUJ-MAMM 1592 - MPUJ-MAMM 1618). All the individuals that were not collected were marked with consecutive numbers on the wing membrane using a tattoo machine and subsequently released to identify possible recaptures during the sampling period. This procedure was made to prevent a double count of individuals during the sampling and avoid bias in the estimation of capture success.

\section{Statistical analysis}

Capture success was calculated using the number of captured individuals per sampling effort (individuals $x$ nights/hours $x$ total nets) (Pérez-Torres 2004) for each stratum and overall. The standardization of the calculation of capture success was made by considering the variations in sampling effort for the two-forest stratum. This formula is a relative and standardized measure which enables the direct comparison of capture success values of both strata by $t$-paired test.

The capture frequency ( $\mathrm{Ci}=$ individuals captured in 100 hours-net) (Bernard 2001, Kalko \& Handley 2001) was calculated to determine the predominance of each bat species to the upper part of the forest (AHF). The index of predominance for the upper part of the forest was then calculated for each species as follows $\mathrm{CP}=\left(\mathrm{Ci}_{\mathrm{AHF}} \times 100\right) /\left(\mathrm{Ci}_{\mathrm{AHF}}\right.$ $+\mathrm{Ci}_{\mathrm{U}}$ ), which is expressed in percentage (Henry et al. 2004). For this study 0 represents a species that was only captured in the understory and 100 a species that was exclusively captured at the AHF level. For the most abundant species (more than 10 individuals), that were captured both in the AHF and the understory during de 16 nights of sampling, a $t$-paired test was applied to identify significant differences of the presence of the species in one stratum or another. A Wilcoxon signed rank-test (T) (Wilcoxon 1945) was applied for Artibeus planisrostris, because their values were not normally distributed.

All bats captured were gently placed on graph paper to draw the silhouette of one of their wings. These silhouettes were used to calculate the wing area $S\left(\mathrm{~m}^{2}\right)$, the handwing area (Snw), and the arm-wing area (Saw), described by Norberg \& Rayner (1987), using an area meter LI-COR (model LI-3100). Morphological wing variables were also calculated as follow: body mass $(\mathrm{M}=\mathrm{Kg})$, aspect ratio $\left(A=\right.$ wingspan $\left.{ }^{2} / S\right)$, wing loading $(W L=M \times g / S)$ (where $g$ is the rate of gravitational acceleration) and tip shape index (I) (Norberg \& Rayner 1987).

To test the association between the indexes of wing morphology of each species with three or more individuals (Supplementary material), we used generalized linear models (GLM), using the $\mathrm{g} / \mathrm{m}$ function from the 'stats' package in the $R$ platform (version 3.6.1) (R Core Team 2018). Generalized linear models were fitted using CP as the predicted variable, A, WL, and I as predictors. GLMs were fitted to test the residual distribution. Because CP is an integer (count) variable, separate models with both Poisson and negative binomial residual distributions were used. Finally, three separate models were considered, including only one predictor variable (i.e., one for each predictor), to avoid potential collinearity issues. These five models were compared and based on the second-order Akaike's Information Criterion (AICC) (i.e., preferring the model with the lowest AICC with a $\triangle \mathrm{AIC}$ higher than two units from the second most adequate model) (Wagenmakers \& Farrell 2004), which is advocated when sample size is relatively low (<40) (Burnham \& Anderson 2002). To accomplish this, we implemented the ICtab function from the 'bbmle' package in $\mathrm{R}$.

\section{RESULTS}

We captured a total of 170 individuals of 13 bat species with no recaptures. The capture success (E) was 0.0796 individuals/hour-net and was substantially higher in the AHF level ( 0.1236 individuals/hour-net) than in the understory (0.0481 individuals/hours-net) $(t 15=4.24, p<0.05)$.

The frugivore bats (Artibeus planirostris, Artibeus lituratus, Carollia brevicauda, Carollia castanea, Carollia perspicillata, Sturnira lilium, Uroderma bilobatum, Platyrrhinus helleri and Dermanura anderseni) were more abundant than insectivore bats (Lophostoma silvicolum and Rogheessa io) and the two-bat species considered omnivores (Phyllostomus elongatus and Phyllostomus hastatus). For $A$. planirostris, A. lituratus, U. bilubatum, S. lilium, P. helleri, $P$. hastatus, $C$. brevicauda and $R$. io values of CP represented more than $50 \%$ of the captures (Table 1 ).

The number of captured individuals was significantly higher in the AHF than in the understory for both $A$. planirostris $(\mathrm{T}=6.0, \mathrm{p}<0.05)$ and $U$. bilobatum $(t 15=2.67$, $\mathrm{p}<0.05$ ) but did not differ significantly in $C$. brevicauda $(t 15=-$ $0.12, p>0.05$ ). Captures of the remaining species were too infrequent to be analyzed. 
Regarding the preference for AHF GLM's with Poisson (log link function) (Model 1), and negative binomial error distributions (Model 2) were fitted. However, only in the model with Poisson error distribution, A, WL, and I were significant predictors of CP (Table 2).

We then reduced these parametrized models creating three simplified models, each with only one predictor variable for the seven species with three or more individuals captured. These models were fitted with a Poisson (log link function) distribution, and all predictors significantly influenced CP (Table 3).

Finally, we compared these five models using secondorder Akaike's information criterion (AICC), Akaike weights (wi(AICC)) and $\triangle A I C$ (Table 4). As expected, this analysis showed that the model including only aspect ratio as the predictor was not only the most parsimonious, but also the model with the lowest AICC, $\triangle \mathrm{AICC}$ and higher wi(AIC), showing that aspect ratio is the most determinant variable that affects $C P$.

Table 1 - Species, bat captures, number of species, sampling effort (hours/net) and index of predominance for the upper part of the forest (CP), obtained for the assemblage of bats of the Guacharacal forest in September 2009. AHF= Available Height for Foraging, U= Understory.

\begin{tabular}{|c|c|c|c|c|c|c|}
\hline \multirow{2}{*}{ Family } & \multirow{2}{*}{ Subfamily } & \multirow{2}{*}{ Species } & \multicolumn{3}{|c|}{ Bat captures } & \multirow{2}{*}{$\begin{array}{l}\text { CP } \\
(\%)\end{array}$} \\
\hline & & & Total & AHF & U & \\
\hline \multirow{12}{*}{ Phyllostomidae } & \multirow{6}{*}{ Stenodermatinae } & Artibeus planirostris (Spix, 1823) & 101 & 68 & 33 & 74 \\
\hline & & Artibeus lituratus (Olfers, 1818) & 6 & 4 & 2 & 74 \\
\hline & & Uroderma bilobatum Peters, 1866 & 20 & 17 & 3 & 89 \\
\hline & & Sturnira lilium (E. Geoffroy, 1810) & 6 & 6 & 0 & 100 \\
\hline & & Dermanura anderseni (Osgood, 1916) & 2 & 0 & 2 & 0 \\
\hline & & Platyrrhinus helleri (Peters, 1866) & 2 & 2 & 0 & 100 \\
\hline & \multirow{3}{*}{ Phyllostominae } & $\begin{array}{l}\text { Lophostoma silvicolum d'Orbigny, } \\
1836\end{array}$ & 4 & 0 & 4 & 0 \\
\hline & & Phyllostomus hastatus (Pallas, 1767) & 1 & 1 & 0 & 100 \\
\hline & & $\begin{array}{l}\text { Phyllostomus elongatus (E. Geoffroy, } \\
\text { 1810) }\end{array}$ & 1 & 0 & 1 & 0 \\
\hline & \multirow{3}{*}{ Carollinae } & Carollia brevicauda (Schinz, 1821) & 23 & 11 & 12 & 56 \\
\hline & & Carollia castanea (H. Allen, 1890) & 2 & 0 & 2 & 0 \\
\hline & & Carollia perspicillata (Linnaeus,1758) & 1 & 0 & 1 & 0 \\
\hline Vespertilionidae & Vespertilioninae & Rhogeessa io Thomas, 1903 & 1 & 1 & 0 & 100 \\
\hline Total bat captures & & & 170 & 110 & 60 & \\
\hline Number of species & & & 13 & 8 & 9 & \\
\hline Sampling effort & & & 2136 & 890 & 1246 & \\
\hline
\end{tabular}

Table 2 - Results of separate GLMs testing combined effects of predictors on the index of predominance for the upper part of the forest (CP), by error distribution, for the seven species with three or more individuals captured. Significant effects are in bold.

\begin{tabular}{|c|c|c|c|c|c|c|}
\hline \multirow[b]{2}{*}{ Predictors } & \multicolumn{3}{|c|}{ Model 1} & \multicolumn{3}{|c|}{ Model 2} \\
\hline & $\begin{array}{l}\text { Incidence } \\
\text { Rate Ratios }\end{array}$ & $\begin{array}{c}\text { 95\% confidence } \\
\text { interval }\end{array}$ & $p$ & $\begin{array}{l}\text { Incidence } \\
\text { Rate Ratios }\end{array}$ & $\begin{array}{l}\text { 95\% confidence } \\
\text { interval }\end{array}$ & $p$ \\
\hline (Intercept) & 0.42 & $0.07-2.40$ & 0.329 & 0.42 & $0.00-1566.78$ & 0.849 \\
\hline Aspect ratio & 1.59 & $1.25-2.03$ & $<0.001$ & 1.59 & $0.51-5.00$ & 0.482 \\
\hline Wing Loading & 0.95 & $0.92-0.99$ & 0.011 & 0.95 & $0.80-1.14$ & 0.627 \\
\hline Tip Index & 2.50 & $1.34-4.67$ & 0.004 & 2.50 & $0.13-47.15$ & 0.583 \\
\hline Observations & & 7 & & & 7 & \\
\hline $\mathrm{R}^{2}$ Nagelkerke & & 1.000 & & & 1.000 & \\
\hline
\end{tabular}




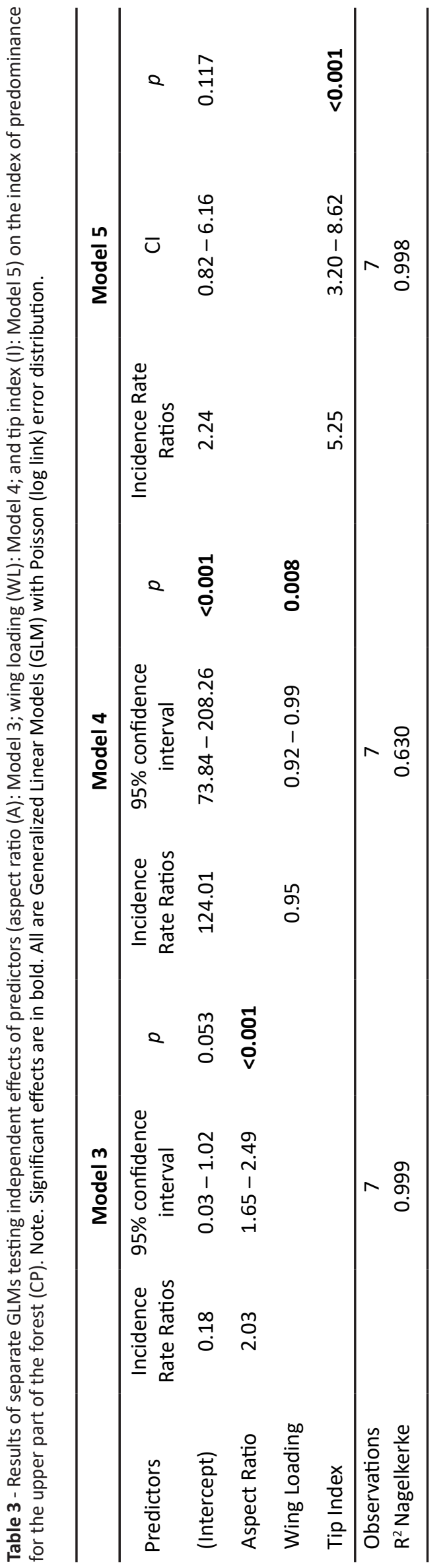

Table 4 - Performance criteria of generalized linear models (GLM's) with second-order Akaike's Information Criterion (AICC) and Akaike weight (wi(AIC)). Each model were developed for the seven species with three or more individuals captured

\begin{tabular}{lcccc}
\hline Model & AICc & AAICc & df & $\mathbf{w}_{\mathbf{i}}($ AICc $)$ \\
\hline Model 3 & 161.42 & 0.00 & 2 & 0.8894 \\
Model 1 & 167.58 & 6.16 & 4 & 0.0409 \\
Model 2 & 167.58 & 6.16 & 4 & 0.0409 \\
Model 5 & 168.29 & 6.87 & 2 & 0.0287 \\
Model 4 & 203.54 & 42.12 & 2 & 0.0000 \\
\hline
\end{tabular}

\section{DISCUSSION}

As expected, the understory had a higher level of spatial complexity due to higher percentage of vegetation cover and higher number of branches, which is reflected in an increase in foliage density compared to the AHF. This is common in most tropical forests in which herbaceous plants are characterized by abundant leaves and branches, generating high levels of spatial complexity in the understory zone (Murphy \& Lugo 1986, Díaz 2006). As a result, bats either avoid plant-based obstacles when moving through this layer, which could require greater energy expenditure, or completely avoid very complex parts of the forest, such as the understory (Norberg 1994, Altringham 1996).

The changes of $\mathrm{CP}$ in response to variation in wing aspect ratio $(A)$ of different species, supports the hypothesis arising from the aerodynamic theory of flight that explicitly predicts a direct relationship between bat wing morphology and the complexity of the layer through which they fly (Norberg \& Rayner 1987). Species with higher aspect ratio value (e.g., A. planirostris, A. lituratus, $U$. bilobatum and S. lilium) were more commonly captured in the AHF level, a space characterized by its low level of complexity. In addition, these frugivore species often carry fruits equivalent to $40 \%$ of their body weight, these aspect ratio values may potentially compensate the effort of transporting these great loads, enabling them to reduce their speed when flying through vegetation (Norberg \& Rayner 1987). The species of genus Artibeus are commonly captured in neotropical forests in all vertical stratum, but it is generally assumed that large species, such as $A$. lituratus, are canopy-foragers (Voigt 2010, Rex et al. 2011, Gregorin et al. 2017).

In contrast, species with wider wings had correspondingly lower $\mathrm{CP}$ values, indicating that they are more likely to be caught through the understory. Accordingly, low wing aspect ratios facilitate a slower, more maneuverable flight inside the vegetation's complex zone, such as the case of Lophostoma silvicolum, or short flights at high speed, in the case of the Carollia brevicauda and Carollia castanea (Norberg $\&$ Rayner 1987). These species have also been recognized as understory foragers in previous studies, regarding wing characteristics and resource specialization, two elements that are complementary for explanatory purposes in this context (Rex et al. 2011). 
The results of this study provide broad support to other authors' observations (Simmons \& Voss 1998, Cosson et al. 1999, Bernard 2001, Kalko \& Handley 2001, Rex et al. 2011, Gregorin et al. 2017), which indicate that bats intensively use different layers of the forest, from the ground to the canopy level. As such, the integrity and complexity of the forest are important factors affecting the composition, abundance, and probably the function of bat assemblages. It is clear, therefore, that the organization of bat assemblages must be understood with relation to a species' wing morphology, as well as to its ecological and behavioral requirements (e.g. diet food capture and roosting).

The primary food sources for $A$. planirostris are the fruits of the genus Ficus (Barquez et al. 1991, 1993, Calonge 2009) with a possible specialization in fruits of the genus Vismia (Willig 1983, Willig et al. 1993). Species of both Ficus and Vismia were present in the AHF zone in the study area, suggesting that $A$. planirostris forages preferentially in the AHF zone in search of these resources. Nevertheless, Pereira et al. (2010) reported that this species seemed to show no clear preference for either of the two strata. This result could be related to the fact that this study was in an area that was poor in Ficus species.

Fig-eating bats with larger body mass usually harvest fruits in the canopy, suggesting that the fruit type consumed also exerts strong pressure on the vertical distribution of bat species (Voigt 2010). Studies performed by Bernard (2001), Kalko \& Handley (2001), Pereira et al. (2010) and Gregorin et al. (2017) suggested that U. bilobatum is specialized in canopy foraging as they are consumers of Ficus spp. commonly located in the canopy and subcanopy layers (Handley 1991, Kalko et al. 1996, Calonge 2009). However, a recent study proposed that most bat species, especially phyllostomid, used the understory more often for several reasons: (i) to commute between foraging sites, (ii) because a complex understory provides advantages in terms of predator avoidance, and (iii) to select roosting sites (Rex et al. 2011). In our case, the presence of $U$. bilobatum in the understory may be related with the presence of Sabal mauritiformis in this layer. This plant species is crucial for these bats survival due to its umbrella architecture for roosting (RodríguezHerrera et al. 2007). For the rest of the species captured, the number of individuals (less than 10) did not allow us to make robust conclusions about their vertical stratification patterns in the forest, regarding resource distribution.

It is important to underline that nine of the 13 species of this bat assemblage were frugivore, as is commonly found in Neotropical forests sampled with mist nets (Calonge et al. 2010, Vela-Vargas \& Pérez-Torres 2012, Racero-Casarrubia et al. 2015, Ríos-Blanco \& Pérez-Torres 2015). This pattern is probably related to the sampling method since low representation of insectivorous bats is associated with the capacity of these species to detect and avoid mist nets (Ortegón-Martínez \& Pérez-Torres 2007). It could also be associated with the large radiation of phyllostomid bats in the neotropics, which explains the dominance of phyllostomid bats in the assemblages of this region (Mantilla-Meluk et al. 2009).
In summary, the abundance of $A$. planirostris and $U$. bilobatum differed significantly in each layer, with a high prevalence of captures in the AHF zone. This supports the results of Pérez-Torres (2004), who reported that these species are particularly sensitive to vegetation structure at different heights in tropical forests. Therefore, it is crucial to consider in future studies the response of these species to changes or loss of food resources on these strata, e. g., Ficus spp. and Cecropia spp. tall trees, since it could be associated with the decrease or loss of these phyllostomid populations, which play an essential role in the process of seed dispersal (Thomas et al. 1988, Fleming \& Sosa 1994, Whitmore 1997, Medellin \& Gaona 1999). Changes in food resources in the AHF could therefore affect natural regeneration and alter the demographic and genetic structure of plants that depend on bats for reproduction or dispersal, such as Ficus spp. and Cecropia spp., likely dispersed by $A$. planirostris and U. bilobatum (Pérez-Torres 2004). As Pereira et al. (2010) highlight, the preservation of rich and complete bat assemblages in Neotropical forests depends on maintaining the integrity of the vertical stratification of the forest.

We consider that the study of bats vertical stratification still represents a challenge because of low capture rates for several species, different capture efforts, installation and configuration of elevated mist-nets, and the variation of net location on the upper part of the forest (Kalko \& Handley 2001). This study could be complemented with acoustic monitoring for the inclusion of the aerial insectivores (mostly vespertilionids and emballonurids) for a more representative sample. However, we proved that the use of canopy and understory mist nets is very important when conducting bat inventories in highly diverse tropical forest (Pereira et al. 2010, Rex et al. 2011, Gregorin et al. 2017).

\section{ACKNOWLEDGMENTS}

We thank Paúl Betancur (Natural Reserve of the Civil Society Hacienda Betancí-Guacamayas) for cooperation and hospitality, Jesús Ballesteros (Universidad de CórdobaColombia) for supporting access to the study area, the members of the Laboratorio de Fisiología Vegetal (Pontificia Universidad Javeriana PUJ), Diego Higuera for help with canopy sampling technique, Dr. Juan David Leongómez for collaboration with statistical analysis (Universidad El Bosque-Colombia), Dr. Trevor Williams (INECOL-México) for collaboration with the revision of this manuscript, and the members of the Laboratorio de Ecología Funcional (PUJ) for their support and cooperation. This study was part of the project "Bats in extensive silvopastoral and conventional livestock systems (Caribbean region of Colombia)" (PUJ-ID: 5688). 


\section{REFERENCES}

AGUIRRE, L. F., HERREL, A., VAN DAMME, R. \& MATHYSSEN, E. (2002). Ecomorphological analysis of trophic niche partitioning in a tropical savanna bat community. Proc. R. Soc. Lond. B, 296(1497): 1271-1278. https://doi. org/10.1098/rspb.2002.2011

ALTRINGHAM, J. D. (1996). Bats: biology and behaviour. ed.: Oxford University Press. New York, EEUU. 262 pp.

ANDERSON, D. L., KOOMJIAN, W., FRENCH, B., ALTENHOFF, S. R. \& LUCE, J. (2015). Review of rope-based access methods for the forest canopy: safe and unsafe practices in published information sources and a summary of current methods. Methods Ecol Evol, 6(8): 865-872. https://doi.org/10.1111/2041-210X.12393

ASCORRA, C., SOLARI, S. \& WILSON, D. E. (1996). Diversidad y ecología de los quirópteros en Pakitza. In: The biodiversity of Southeastern Peru. ed.: Smithsonian Institution Press \& Editorial Horizonte. Lima, Perú. p.593-612.

AUGUST, P. V. (1983). The role of habitat complexity and heterogeneity in structuring tropical mammal communities. Ecology, 64(6): 1495-1507. https://doi. org/10.2307/1937504

BALLESTEROS, J., FERNÁNDEZ, C. \& DUEÑAS, P. (2006). Introducción a la biodiversidad faunística del departamento de Córdoba, Colombia. Informe técnico. Universidad de Córdoba. Montería, Colombia. 260 pp.

BALLESTEROS-CORREA, J. (2015). Efecto del manejo silvopastoril y convencional de ganadería extensiva sobre el ensamblaje de murciélagos asociados a fragmentos de bosque seco tropical en Córdoba, Colombia. PhD thesis, Universidad Javeriana, Bogotá D.C., Colombia.

BARQUEZ, R. M., MARES, M. A. \& OJEDA, R. A. (1991). Mammals of Tucumán. ed.: Oklahoma Museum of Natural History. Oklahoma City, EEUU. 282 pp.

BARQUEZ, R. M., GIANNINI, N. P. \& MARES, M. A. (1993). Guide to the bats of Argentina. ed.: University of Oklahoma Press. Oklahoma City, EEUU. 119 pp.

BERNARD, E. (1997). Vertical stratification of bat communities in tree fall gaps in primary forest of central Amazonia. MSc thesis, Brazilian National Institute for Research in the Amazon, Manaus, Brazil.

BERNARD, E. (2001). Vertical stratification of bat communities in primary forests of Central Amazon, Brazil. Journal of Tropical Ecology, 17(1): 115-126. https://doi. org/10.1017/S0266467401001079

BOBROWIEC, P. E. D. \& TAVARES, V. (2017). Establishing baseline biodiversity data prior to hydroelectric dam construction to monitoring impacts to bats in the Brazilian Amazon. PloS One, 12(9): e0183036. https:// doi.org/10.1371/journal.pone.0183036
BURNHAM, K. P. \& ANDERSON, D. R. (2002). Model selection and multimodel inference. A practical informationtheoretic approach. ed.: Springer-Verlag New York. New York, EEUU. 488 pp. https://doi.org/10.1007/b97636

CALONGE, B. H. (2009). Dieta y estructura trófica del ensamblaje de murciélagos en un sistema de ganadería extensiva en remanentes de bosque seco tropical en Córdoba (Colombia). Tesis de pregrado, Pontificia Universidad Javeriana, Bogotá D.C., Colombia.

CALONGE, B., VELA-VARGAS, I. M. \& PÉREZ-TORRES, J. (2010). Murciélagos asociados a una finca ganadera en Córdoba (Colombia). Revista MVZ Córdoba, 15(1): 19381943.

CASTELLANOS-CASTRO, C. \& NEWTON, A. C. (2015). Environmental heterogeneity influences successional trajectories in colombian seasonally dry tropical forests. Biotropica, 47(6): 660-671. https://doi.org/10.1111/ btp.12245

COSSON, J. F., PONS, J. M. \& MASSON, D. (1999). Effects of forest fragmentation on frugivorous and nectarivorous bats in French Guiana. Journal of Tropical Ecology, 15(4): 515-534. https://doi.org/10.1017/S026646749900098X

DÍAZ, J. M. (2006). Bosque seco tropical Colombia. Primera edición. ed.: I/M Editores. Cali, Colombia. https://www. imeditores.com/banocc/seco/indice.htm

FINDLEY, J. S. \& WILSON, D. E. (1982). Ecological significance of chiropteran morphology. In: Ecology of bats. ed.: Plenum publishing corporation press. New York, EEUU. p.243-260.

FLEMING, T. \& SOSA, V. (1994). Effects of nectarivorous and frugivorous mammals on reproductive success of plants. Journal of Mammalogy, 75(4): 845-851. https://doi. org/10.2307/1382466

GAST, F., ESCOBAR-SARRIA, F., REPIZZO, A., ALVAREZ, M., MENDOZA-CIFUENTES, H. \& VILLAREAL-LEAL, H. F. (1997). El bosque seco tropical (Bs-T) en Colombia. Instituto de investigaciones de recursos biológicos Alexander von Humboldt, Villa de Leyva, Boyacá, Colombia.

GREGORIN, R., BERNARD, E., LOBÃO, K. W., OLIVEIRA, L. F., MACHADO, F. S., GIL, B. B. \& TAVARES, V. C. (2017). Vertical stratification in bat assemblages of the Atlantic Forest of south-eastern Brazil. Journal of Tropical Ecology, 33(5): 299-308. https://doi.org/10.1017/S026646741700027X

HANDLEY, C. O., WILSON, D. E. \& GARDNER, A. L. (1991). Demography and natural history of the common fruit bat, Artibeus jamaicensis, on Barro Colorado Island, Panama. Smithsonian Contributions to Zoology, 511: 3-173. https://doi.org/10.5479/si.00810282.511 
HAYDEN, B., GREENE, D. F. \& QUESADA, M. (2010). A field experiment to determine the effect of dry-season precipitation on annual ring formation and leaf phenology in a seasonally dry tropical forest. Journal of Tropical Ecology, 26(2): 237-242. https://doi.org/10.1017/ S0266467409990563

HENRY, M., BARRIÈRE, P., GAUTIER-HION, A. \& COLYN, M. (2004). Species composition, abundance and vertical stratification of a bat community (Megachiroptera: Pteropodidae) in a West African rain forest. Journal of Tropical Ecology, 20(1): 21-29. https://doi.org/10.1017/ S0266467404006145

HODGKISON, R., BALDING, S. T., ZUBAID, A. \& KUNZ, T. H. (2004). Habitat structure, wing morphology, and the vertical stratification of Malaysian fruit bats (Megachiroptera: Pteropodidae). Journal of Tropical Ecology, 20(6): 667-673.https://doi.org/10.1017/ S0266467404001737

KALKO, E. K. V., HANDLEY, C. \& HANDLEY, D. (1996). Organization, diversity, and long-term dynamics of a Neotropical bat community. In: Long-term studies of vertebrate communities. ed.: Academic Press. Los Angeles, EEUU. p.503-553. https://doi.org/10.1016/ B978-012178075-3\%2F50017-9

KALKO, E. K. V. (1997). Diversity in tropical bats. In: Tropical biodiversity and systematic. ed.: Zoologisches Forschungsinstitut und Museum Alexander König. Bonn, Germany. p.13-43.

KALKO, E. K. V. \& HANDLEY, C. O. (2001). Neotropical bats in the canopy: diversity, community structure, and implications for conservation. Plant Ecology, 153: 319333. https://doi.org/10.1023/A:1017590007861

LEMMON, P. E. (1956). A spherical densiometer for estimating forest overstory density. Forest Science, 2(4): 314-320. https://doi.org/10.1093/forestscience/2.4.314

LEMMON, P. E. (1957). A new instrument for measuring forest overstory density. J Forest, 55: 667-668.

LÓPEZ-GONZÁLEZ, C., PRESLEY, S. J., LOZANO, A., STEVENS, R. D. \& HIGGINS, C. L. (2015). Ecological biogeography of Mexican bats: the relative contributions of habitat heterogeneity, beta diversity, and environmental gradients to species richness and composition patterns. Ecography, 38(3): 261-272. https://doi.org/10.1111/ ecog.00813

MANTILLA-MELUK, H., JIMÉNEZ-ORTEGA, M. \& BAKER, R. J. (2009). Phyllostomid bats of Colombia: annotated checklist, distribution, and biogeography. Special Publications Museum of Texas Tech University, 56: 1-37.

MARQUES, J. T., RAMOS PEREIRA, M. J., MARQUES, T. A., SANTOS, C. D., SANTANA, J., BEJA, P. \& PALMEIRIM, J. M. (2013) Optimizing sampling design to deal with mist-net avoidance in Amazonian birds and bats. PLOS ONE, 8(9): e74505. https://doi.org/10.1371/journal.pone.0074505
MEDELLIN, R. A. \& GAONA, O. (1999). Seed dispersal by bats and birds in forest and disturbed habitats of Chiapas, Mexico. Biotropica, 31(3): 478-485. https://doi. org/10.1111/j.1744-7429.1999.tb00390.x

MURPHY, P. G. \& LUGO, A. E. (1986). Ecology of tropical dry forest. Annu Rev of Ecol Syst, 17: 67-88. https://doi. org/10.1146/annurev.es.17.110186.000435

NORBERG, U. M. \& RAYNER, J. M. V. (1987). Ecological morphology and flight in bats (Mammalia: Chiroptera): wing adaptations, flight performance, foraging strategy and echolocation. Phil. Trans. R. Soc. Lond. B, 316: 335427. https://doi.org/10.1098/rstb.1987.0030

NORBERG, U. M. (1994). Wing design, flight performance and habitat use in bats. In: Ecological morphology. ed.: The University of Chicago Press. Chicago, EEUU. p.205239.

ORTEGÓN-MARTÍNEZ, D. \& PÉREZ-TORRES, J. (2007). Estructura y composición del ensamblaje de murciélagos (Chiroptera) asociado a un cafetal con sombrío en la Mesa de los Santos (Santander) Colombia. Actualidades biológicas, 29(87): 215-228.

PEREIRA, M. J. R., MARQUES, J. T. \& PALMEIRIM, J. M. (2010). Vertical stratification of bat assemblages in flooded and unflooded Amazonian forests. Current Zoology, 56(4): 469-478. https://doi.org/10.1093/czoolo/56.4.469

PÉREZ-TORRES, J. (2004). Dinámica del ensamblaje de murciélagos en respuesta a la fragmentación en bosques nublados: un modelo de ecuaciones. PhD thesis, Pontificia Universidad Javeriana, Bogotá D.C., Colombia. https://doi.org/10.13140/RG.2.2.14190.82245/1

PINEDA-GUERRERO, A., GONZÁLEZ-MAYA, J. F. \& PÉREZTORRES, J. (2015). Conservation value of forest fragments for medium-sized carnivores in a silvopastoral system in Colombia. Mammalia. International Journal of the Systematics, Biology and Ecology of Mammals, 79(1): 115119. http://dx.doi.org/10.1515/mammalia-2013-0050

PIZANO, C., CABRERA, M. \& GARCÍA, H. (2014). El bosque seco tropical en Colombia. Generalidades y contexto. In: Bosque seco tropical en Colombia. ed.: Instituto de investigación de recursos biológicos Alexander von Humboldt. Bogotá D.C., Colombia. p.36-47.

PRADO, D. E. (2000). Seasonally dry forests of tropical South America: from forgotten ecosystems to a new phitogeographic unit. Edinburgh Journal of Botany, 57(3): 437-461. https://doi.org/10.1017/S096042860000041X

R CORE TEAM. (2018). R: A language and environment for statistical computing. R Foundation for Statistical Computing, Vienna, Austria. Available online at https:// www.R-project.org/.

RACERO-CASARRUBIA, J., BALLESTEROS-CORREA, J. \& PÉREZTORRES, J. (2015). Mamíferos del departamento de Córdoba-Colombia: historia y estado de conservación. Biota Colombiana, 16(2): 128-148. 
RAMÍREZ-CHAVES, H., SUÁREZ-CASTRO, A. \& GONZÁLEZMAYA, J. F. (2016). Cambios recientes a la lista de los mamíferos de Colombia. Mammalogy Notes, 3(1): 1-9.

RANGEL-CH, O. J., CANTILLO-H, E. E. \& GARAY, H. (2011). La estructura y el patrón de riqueza de la vegetación en localidades del departamento de Córdoba. In: Colombia Diversidad Biótica XI. Patrones de la estructura y de la riqueza de la vegetación en Colombia. ed.: Universidad Nacional de Colombia. Bogotá D.C., Colombia. p.203244.

REX, K., MICHENER, R., KUNZ, T. H. \& VOIGT, C. C. (2011). Vertical stratification of Neotropical leaf-nosed bats (Chiroptera: Phyllostomidae) revealed by stable carbon isotopes. Journal of Tropical Ecology, 27(3): 211-222. https://doi.org/10.1017/S0266467411000022

RÍOS-BLANCO, M. C. \& PÉREZ-TORRES, J. (2015). Dieta de las especies dominantes del ensamblaje de murciélagos frugívoros en un bosque seco tropical (Colombia). Journal of Neotropical Mammalogy, 22(1): 103-111.

RODRÍGUEZ-HERRERA, B., MEDELLIN, R. A. \& TIMM, R. M. (2007). Murciélagos neotropicales que acampan en hojas. ed.: Instituto Nacional de Biodiversidad INBio. Santo Domingo de Heredia, Costa Rica. 184 pp.

SEIDEL, D., FLECK, E., LEUSCHNER, C. \& HAMMETT, T. (2011). Review of ground-based methods to measure the distribution of biomass in forest canopies. Ann For Sci, 68: 225-244. https://doi.org/10.1007/s13595-0110040-z

SELAYA, A. (2001). Estructura de la comunidad de murciélagos en tres tipos de bosque en el valle del Sacta (ChapareBolivia). Thesis, Universidad Mayor de San Simón, San Simón, Bolivia.

SELAYA, A. (2007). La importancia de estudios de ecomorfología en la investigación y conservación de murciélagos. In: Historia natural, distribución y conservación de los murciélagos de Bolivia. ed.: Centro de ecología y difusión Simón I, Santa Cruz. p.14-21.

SIMMONS, N. B. \& VOSS, R. S. (1998). The mammals of Paracou, Frech Guiana: a Neotropical lowland rain forest fauna. Part 1. Bats. Bulletin American Museum Natural History, 237: 1-219.

SOLARI, S., MUÑOZ-SABA, Y., RODRÍGUEZ-MAHECHA, J. V., DEFLER, T. R., RAMÍREZ-CHAVES, H. E. \& TRUJILLO, F. (2013). Riqueza, endemismo y conservación de los mamíferos de Colombia. Mastozoología Neotropical, 20(2): 301-365.
STATON, T. \& POULTON, S. (2012). Seasonal variation in bat activity in relation to detector height: a case study. Acta Chiropterologica, 14(2): 401-408. https://doi. org/10.3161/150811012X661710

THOMAS, D. W., CLOUTIER, D., PROVENCHER, M. \& HOULE, C. (1988). The shape of bird-and bat-generated seed shadows around a tropical fruiting tree. Biotropica, 20(4): 347-348. https://doi.org/10.2307/2388330

VELA-VARGAS, M. \& PÉREZ-TORRES, J. (2012). Murciélagos asociados a remanentes de bosque seco tropical en un sistema de ganadería extensiva (Colombia). Chiroptera Neotropical, 18(1): 1089-1100.

VILLALOBOS, F. \& ARITA, H. T. (2014). Morphological diversity at different spatial scales in a Neotropical bat assemblage. Oecologia, 176(2): 557-568. https://doi. org/10.1007/s00442-014-3039-y

VOIGT, C. C. (2010). Insights into strata use of forest animals using the 'canopy effect'. Biotropica, 42(6): 634-637. https://doi.org/10.1111/j.1744-7429.2010.00703.x

WAGENMAKERS, E. J. \& FARRELL, S. (2004). AIC model selection using Akaike weights. Psychonomic Bulletin \& Review, 11(1): 192-196.

WHITMORE, T. (1997). Tropical forest disturbance, disappearance, and species loss. In: Tropical forest remnants: ecology, management, and conservation of fragmented communities. ed.: University of Chicago Press. Chicago, EEUU. p.2-12.

WILCOXON, F. (1945). Individual comparisons by ranking methods. Biometrics, 1(6): 80-83. https://doi. org/10.2307/3001968

WILLIG, M. (1983). Composition, microgeographic variation, and sexual dimorphism in Caatingas and Cerrado bat communities from northeast Brazil. Bulletin of Carnegie Museum of Natural History, Carnegie Museum of Natural History, 23: 1-131.

WILLIG, M., CAMILO, G. \& NOBLE, S. (1993). Dietary overlap in frugivorous and insectivorous bats from edaphic cerrado habitats of Brazil. Journal of Mammalogy, 74(1): 117-128. https://doi.org/10.2307/1381910 